\title{
Sex Hormone-binding Globulin Selectively Modulates Estradiol-regulated Genes in MCF-7 Cells
}

Authors

Affiliations
M. G. Catalano ${ }^{1}$, L. Costantino ${ }^{1}$, R. Frairia ${ }^{1}$, G. Boccuzzi ${ }^{1,2}$, N. Fortunati ${ }^{2}$

${ }^{1}$ Department of Clinical Physiopathology, University of Turin, Turin, Italy

${ }^{2}$ Oncological Endocrinology, ASO San Giovanni Battista, Turin, Italy

\section{Key words \\ - SHBG \\ - estradiol \\ gene expression \\ - breast cancer}

received 28.7.2006

accepted 27.11.2006

Bibliography

DOI 10.1055/s-2007-973814

Horm Metab Res 2007;

39: 288-294

(c) Georg Thieme Verlag KG

Stuttgart . New York.

ISSN 0018-5043

\section{Correspondence}

N. Fortunati M.D.

Laboratorio Endocrinologia Oncologica

Via Genova 3

10126 Torino

Italy

Tel.: + 39/011/6705360

Fax: $+39 / 011 / 6705366$

nfortunati@molinette.

piemonte.it

\section{Abstract \\ $\nabla$}

Human sex hormone-binding globulin inhibits the effects of estradiol on proliferation and apoptosis of breast cancer cells. We report here the effect of sex hormone-binding globulin on estradiol regulation of gene expression in MCF-7 breast cancer cells using a selected set of genes. Estradiol upregulates genes that are positive regulators of proliferation (e.g., bcl-2, c-fos, cmyc, cyclin D) or/and related to more aggressive form of breast cancer (e.g. BRCA-1, EGF-R) and downregulates two genes (c-jun and ER $\alpha$ ).

\section{Introduction}

Estradiol increases breast cancer cell proliferation and tumorigenesis $[1,2]$. In recent years, thanks to the advent of microarray technology, the profiling of estrogen-regulated genes in breast cancer cells has become possible. Most studies had identified genes overexpressed in breast cancer or patterns of gene expression related to disease outcome $[3,4]$ and therapy responsiveness [5]. Furthermore, the exact role of estrogen-regulated gene expression in estrogen-sensitive breast cancer cells has also been investigated. In breast cancer cells, estradiol upregulates, among others, genes positively affecting cell proliferation and cell cycle progression, while it downregulates transcriptional repressors, anti-proliferative and pro-apoptotic genes [6]. The differential modulation of these genes, altogether, contributes to the estradiol induction of proliferation and inhibition of apoptosis in breast cancer.

The effects of estradiol on proliferation and apoptosis in breast cancer cells can be efficiently inhibited by Sex Hormone-Binding Globulin (SHBG), a glycoprotein of human plasma that specifically binds androgens and estradiol [7].
Sex hormone-binding globulin modulates only a selected group of estradiol-controlled genes (inhibiting upregulation of bcl-2, c-myc, EGF-R, PR, and downregulation of ER $\alpha$ ), starting 48 hours after treatment. Our study demonstrates that in breast cancer cells, sex hormone-binding globulin is effective on few selected genes which are involved in cell growth and apoptosis or related to cell estrogen-dependence and that the protein regulation of estradiol effect is selected and specific. Sex hormone-binding globulin action in estrogen breast cancer cells is strongly associated to cell growth and estrogen-sensitivity.

Besides acting as steroid carrier, new roles of SHBG on steroid action have emerged $[8,9]$; in particular, the effects of SHBG initiated at the level of the cell membrane $[10,11]$, stimulate a specific intracellular pathway which leads to inhibition of breast cancer cell proliferation. We have demonstrated that SHBG rapidly stimulates cAMP in MCF-7 breast cancer cells [12,13]; as a result of this intracellular pathway stimulation, the effects of estradiol on cancer cell proliferation are inhibited [14]. Moreover, quite recently, SHBG was also reported to abolish the anti-apoptotic effect of estradiol in MCF-7 cells [15]. Therefore, it appears that it is through these active and specific processes, that SHBG inhibits estradiolinduced effects on cancer cell proliferation. This is the first study that determines if these SHBGactivated pathways initiate specific gene transcription.

\section{Materials and Methods}

$\nabla$

\section{Cell Cultures}

Estrogen-dependent MCF-7 breast cancer cells were routinely maintained in $25 \mathrm{~cm}^{2}$ flasks at $37^{\circ} \mathrm{C}$ in $5 \% \mathrm{CO}_{2}$ and $95 \%$ humidity, in RPMI 1640 
(Sigma-Aldrich, St Louis, MO, USA) with the addition of 100 IU/ $\mathrm{ml}$ penicillin and $100 \mu \mathrm{g} / \mathrm{ml}$ streptomycin, and supplemented with $10 \%$ heat inactivated FBS (Euroclone, Wetherby, West York, UK). Once a week, cells were detached with trypsin/EDTA and re-seeded at a dilution of 1:2 and 1:4. Twenty-four hours before experiments, cells were switched to RPMI 1640 without phenol red supplemented with $10 \%$ FBS specifically treated to remove steroids and bovine SHBG.

\section{Gene array}

MCF-7 cells $\left(1.5 \times 10^{6}\right)$ were seeded in $75 \mathrm{~cm}^{2}$ flasks and treated as follows: a) cells under basal conditions; b) cells treated with $10 \mathrm{nM}$ estradiol (Sigma-Aldrich, St. Louis MO, USA) for different times (6, 24, 48, 72 hours); c) cells treated with 50 nM SHBG for 40 minutes. Human SHBG (a gift from G.L. Hammond, B.C. Research Institute for Children's and Women's Health, Vancouver B.C., Canada), was charcoal-treated before use to remove the dihydrotestosterone (DHT) used for storage; d) cells treated with $50 \mathrm{nM}$ SHBG for 40 minutes, thereafter, SHBG was washed off the cells before exposure to estradiol for the time indicated above. All of the treatments were repeated every day when experiment was prolonged over 24 hours.

Human GEArray kits for the study of estrogen-regulated genes (SuperArray, Bethesda, MD) were used to study the gene expression profiles of untreated and treated MCF-7 cells. Hybridization was performed according to manufacturer's instructions. Briefly, by using the TRIzol Reagent (Invitrogen, Groningen, The Netherlands) following the method developed by Chomczynski and Sacchi [16], total RNA was extracted from MCF-7 cells in different conditions. RNA was used as a template for biotinylated probe synthesis. For probe synthesis, each RNA sample ( $7.5 \mu \mathrm{g})$ was combined with a primer mix, and with $80 \mathrm{U}$ AMV reverse transcriptase (Finnzymes, Finland), $50 \mathrm{U}$ Rnase inhibitor (Amersham, Little Chalfont, Buckinghamshire, UK), and a dNTP mix with biotin-16-dUTP (Roche Applied Science, Penzberg, Germany) and was incubated for 120 minutes at $42^{\circ} \mathrm{C}$. Filters were hybridized overnight at $68^{\circ} \mathrm{C}$ with denatured biotinylated cDNA probes; then they were extensively washed and incubated with alkaline phosphatase-conjugated streptavidin (1:5000). Gene expression was detected by chemiluminescence by using the alkaline phosphatase substrate CDP-Star. Spots were photographed with the Kodak EDAS 290 system (Eastman Kodak Company, Rochester, NY). Densitometric analysis was performed by using the Kodak 1D Image Analysis software. The negative control pUC18 DNA was used for background subtraction. The relative abundance of each transcript was estimated by comparing its signal intensity to the signal derived from positive controls, $\beta$-actin and GAPDH. Experiments were performed in triplicate.

\section{RNA extraction and RT-PCR analysis}

MCF-7 cells were seeded in $75 \mathrm{~cm}^{2}$ flasks and treated as above. Total RNA was extracted from cells using TRIzol Reagent (Invitrogen, Groningen, The Netherlands), as above. Total RNA was reverse-transcribed at $42^{\circ} \mathrm{C}$ for 40 minutes using AMV reverse transcriptase (Finnzymes, Finland) and oligodT primer (Invitrogen, Groningen, The Netherlands). The PCR reaction system contained $5 \mu$ l of 10X PCR buffer, $10 \mu$ l of RT product, $0.2 \mathrm{mM}$ dNTP (Finnzymes, Finland), 1.25U Taq DNA polymerase (Finnzymes, Finland), $50 \mathrm{ng}$ each of sense and anti-sense primers in a total volume of $50 \mu \mathrm{l}$. Primers: 5'- CGA CTT CGC CGA GAT GTC CAG GCA G and 3'- ACT TGT GGC CCA GAT AGG CAC CCA G for bcl-2; 5'- GGA AGA AAT TCG AGC TGC TG and 3'- GCT GTC GTT GAG
AGG GTA GG for c-myc; 5' - AGA AGA AAC GGA GGG GAT GGA A and 3'- TTG GGG TGA TGG CTA AAG GAG A for EGF-R; 5'- CAT AAC GAC TAT ATG TGT CCA GCC and 3'- AAC CGA GAT GAT GTA GCC AGC AGC for ER $\alpha$; 5'-CTC ACC CTG AAG TAC CCC ATC G and 3 '-CTT GCT GAT CCA CAT CTG CTG G for $\beta$-actin. The expected PCR products were 389 for bcl-2, 458 bp for c-myc, 424 for EGF$\mathrm{R}, 659$ for $\mathrm{ER} \alpha$, and 885 for $\beta$-actin. Amplification was carried out as follows; for bcl-2: $1 \mathrm{X}\left(95^{\circ} \mathrm{C}, 3 \mathrm{~min}\right) ; 40 \mathrm{X}\left(95^{\circ} \mathrm{C}, 30 \mathrm{sec} ; 65^{\circ} \mathrm{C}\right.$, $\left.1 \mathrm{~min} ; 72^{\circ} \mathrm{C}, 30 \mathrm{sec}\right)$; and $1 \mathrm{X}\left(72^{\circ} \mathrm{C}, 7 \mathrm{~min}\right)$. For c-myc and EGF-R: $1 \mathrm{X}\left(95^{\circ} \mathrm{C}, 3 \mathrm{~min}\right) ; 35 \mathrm{X}\left(95^{\circ} \mathrm{C}, 30 \mathrm{sec} ; 60^{\circ} \mathrm{C}, 30 \mathrm{sec} ; 72^{\circ} \mathrm{C}, 30 \mathrm{sec}\right)$; and $1 \mathrm{X}\left(72^{\circ} \mathrm{C}, 7 \mathrm{~min}\right)$. For $\mathrm{ER} \alpha$ and $\beta$-actin: $1 \mathrm{X}\left(95^{\circ} \mathrm{C}, 3 \mathrm{~min}\right) ; 35 \mathrm{X}\left(95^{\circ} \mathrm{C}\right.$, $\left.30 \mathrm{sec} ; 65^{\circ} \mathrm{C}, 30 \mathrm{sec} ; 72^{\circ} \mathrm{C}, 30 \mathrm{sec}\right)$; and $1 \mathrm{X}\left(72^{\circ} \mathrm{C}, 7 \mathrm{~min}\right)$. PCR products were electrophoresed on $1.5 \%$ agarose gel in the presence of ethidium bromide. Gels were photographed and analyzed with the Kodak 1D Image Analysis software. The net intensity of bands in each experiment was normalized to the intensity of the corresponding $\beta$-actin band before comparison between treated cells and untreated control.

\section{Western blot analysis}

$1 \times 10^{6}$ cells were seeded in $75 \mathrm{~cm}^{2}$ flasks and treated as above for 3 days. After treatment, cells were lysed in RIPA buffer (PBS, $\mathrm{pH}=7.4,1 \%$ Nonidet P40, 0.1\% SDS, 0.5\% sodium deoxycholate, $100 \mu \mathrm{g} / \mathrm{ml}$ PMSF, $30 \mu \mathrm{l}$ aprotinin, $100 \mathrm{mM} \mathrm{NaVO}_{4}$ ), extracted at $4^{\circ} \mathrm{C}$ for 30 minutes, and centrifuged at $4^{\circ} \mathrm{C}$ for 20 minutes at $15000 \times \mathrm{g}$. Equal amounts of protein ( $50 \mu \mathrm{g}$ protein/lane) were subjected to SDS-PAGE ( $\mathrm{T}=8 \%$ ) and electroblotted onto a PVDF membrane; the membrane was probed with the following primary antibodies: anti-bcl-2 ( $\Delta \mathrm{C}-21,1: 400$ dilution, Santa Cruz Biotechnology Inc, Santa Cruz, CA, USA); anti c-myc (\#06-340, 1:500 dilution, Upstate, Lake Placid, NY, USA); anti-ER $\alpha$ (HC-20, 1:500 dilution, Santa Cruz Biotechnology Inc, Santa Cruz, CA, USA); anti-actin (Monoclonal Anti-actin clone AC-40, 1:1000 dilution, Sigma, Saint Louis, MI, USA), to check protein loading. Proteins were detected with ECL Western blot reagents following manufacturer's instructions, and photographed with the Kodak EDAS 290 system (Eastman Kodak Company, Rochester, NY). Densitometric analysis was performed by using the Kodak 1D Image Analysis software.

\section{Statistical analysis}

Data are expressed throughout as means \pm SEM, calculated from at least three different experiments. Statistical comparisons between groups were performed with analysis of variance (oneway ANOVA) and the threshold of significance was calculated with the Bonferroni test. Statistical significance was set at $\mathrm{p}<0.05$.

\section{Results}

$\nabla$

Estradiol and SHBG effect on gene expression in MCF-7 cells

The GEArray technique allowed us to evaluate the expression in MCF-7 cells of 23 genes that are reported in Table 1 . Among them, we could not observe any expression at any time of 6 genes (EGF, ER $\beta, \mathrm{H}$-ras, PRL, telomerase, TGF $\alpha$ ). The remaining 17 genes were expressed in untreated cells at different abundance levels and estradiol regulated 13 of these genes. Estradiol in MCF-7 cells upregulated the expression of 11 genes (bcl-2, BRCA1, Cathepsin D, c-fos, c-myc, Cyclin D, EBAG9, EGF-R, Kera- 
Table 1 Expression of estradiol-regulated genes in MCF-7 cells

\begin{tabular}{|c|c|c|c|c|c|}
\hline \multirow{2}{*}{ Gene Name } & \multirow[t]{2}{*}{ Gene Bank No. } & \multicolumn{4}{|l|}{$10 \mathrm{nM}$ estradiol } \\
\hline & & $6 \mathrm{~h}$ & $24 \mathrm{~h}$ & $48 \mathrm{~h}$ & $72 \mathrm{~h}$ \\
\hline bcl-2 & M14745 & 1.94 & 1.82 & 2.47 & 3.44 \\
\hline BRCA1 & U68041 & 0.93 & 0.95 & 3.66 & 1.77 \\
\hline Cathepsin D & M11233 & 0.96 & 1.55 & 1.86 & 1.65 \\
\hline c-fos & V01512 & 1.98 & 1.99 & 1.65 & 1.50 \\
\hline c-jun & AF022805 & 1.34 & 1.20 & 0.76 & 0.56 \\
\hline c-myc & J00120 & 2.45 & 3.00 & 2.90 & 2.31 \\
\hline COX7RP & АВ007618 & 0.75 & 0.86 & 1.12 & 1.15 \\
\hline Cyclin D & M64349 & 0.82 & 0.86 & 1.66 & 1.52 \\
\hline EBAC9 & АВ007619 & 0.94 & 1.08 & 1.02 & 2.43 \\
\hline EFP & D21205 & 0.85 & 0.86 & 1.54 & 1.20 \\
\hline EGF & X04571 & not detectable & & & \\
\hline EGF-R & X00588 & 1.18 & 1.24 & 1.65 & 2.83 \\
\hline$E R \alpha$ & NM_000125 & 1.16 & 0.61 & 0.34 & 0.37 \\
\hline $\mathrm{ER} \beta$ & AB006590 & not detectable & & & \\
\hline HMG1 & NM_002128 & 0.75 & 0.82 & 0.95 & 1.19 \\
\hline H-ras & NM_005343 & not detectable & & & \\
\hline Keratin 19 & NM_002276 & 0.79 & 1.28 & 2.26 & 1.82 \\
\hline PR & M15716 & 1.93 & 5.31 & 4.75 & 19.9 \\
\hline PRL & M29386 & not detectable & & & \\
\hline pS2 & NM_003225 & 1.15 & 1.32 & 2.42 & 2.00 \\
\hline Telomerase & AF015950 & not detectable & & & \\
\hline TGF $\alpha$ & NM_003236 & not detectable & & & \\
\hline WISP2 & NM_003881 & 0.86 & 0.81 & 1.40 & 1.18 \\
\hline
\end{tabular}

tin 19, PR and pS2) while it downregulated the remaining two genes (c-jun and $\mathrm{ER} \alpha$ ), following different temporal schedules.

SHBG alone had no detectable effect on basal gene expression in MCF-7 cells and its effect on estradiol gene regulation was detectable only after 48-72 hours of treatment. In these experimental conditions, SHBG was effective in modifying estradiol effect on selected genes as showed in Table 2 . We observed, in fact, in MCF-7 cells pre-treated with SHBG an inhibition of estradiol upregulation of bcl-2, c-myc, EGF-R and PR and of estradiol downregulation of $\mathrm{ER} \alpha$.

\section{SHBG regulation of $E_{2}$ stimulated genes involved in cell proliferation and survival}

Accordingly to previous reports, estradiol treatment of MCF-7 cells upregulated bcl-2, a gene widely known for its anti-apoptotic properties; and here we demonstrated that SHBG pretreatment is able to inhibit the estradiol effect. As shown in 0 Fig. 1, panel $\mathbf{A}$, the estradiol upregulation of bcl-2 mRNA was inhibited by SHBG pretreatment. In $\bullet$ Fig. 1, panel B, the effect of estradiol and SHBG/estradiol treatment on bcl-2 protein levels is also reported. Estradiol was significantly efficient in increasing bcl-2 protein levels and pre-treatment with SHBG partially reduced its expression.

- Fig. 2, panel A reports the behavior of c-myc expression. Estradiol upregulated c-myc mRNA expression while SHBG pre-treatment inhibited it. Analysis of protein levels confirmed RT-PCR data ( $\odot$ Fig. 2, panel B).

\section{SHBG regulation of $\mathrm{E}_{2}$ stimulated genes encoding for growth factor receptors}

Among genes encoding for growth factors and upregulated by estradiol, we show here that EGF-R mRNA expression was induced by steroid treatment ( $\bullet$ Fig. 3, panel A) and that SHBG pre-treatment inhibited this estradiol effect. Moreover, the data was confirmed by analysis of protein levels ( $\bullet$ Fig. 3, panel B).

\section{SHBG regulation of steroid receptor expression (ER $\alpha$ and PR)}

Estradiol, as expected, downregulated mRNA expression of its receptor $\mathrm{ER} \alpha$ ( $\odot$ Fig. 4, panel $\mathrm{A}$ ) and after pre-treatment with SHBG mRNA levels of ER returned to basal levels. The same effect was observed as protein levels are concerned ( $\bullet$ Fig. 4, panel B). As progesterone receptor is concerned, we confirmed our previously results [17] indicating that estradiol induces PR expression and that pretreatment with SHBG determine a reduction of PR to basal levels, again at both mRNA and protein levels.

\section{Discussion}

$\nabla$

In the present paper we demonstrate that SHBG affects estradiol gene regulation on selected genes, that are bcl-2, c-myc, EGF-R, $\mathrm{ER} \alpha$ and PR. The effect observed here on bcl-2 expression may be one of the mechanisms elicited by SHBG to restore apoptosis in breast cancer cells under estrogen action. We recently reported [15] that SHBG, after interacting with MCF-7 cell membranes, antagonizes the anti-apoptotic effect of estradiol; thus, the present observation on bcl-2 expression in MCF-7 cells confirms the involvement of SHBG in abrogating the anti-apoptotic effect of estradiol. In fact, the proto-oncogene bcl-2 is widely known to inhibit apoptosis $[18,19]$ and it is over-expressed in many tumors including breast cancer [20]. Estradiol in MCF-7, ZR.75 and T47D breast cancer cells induces bcl-2 gene and cognate protein expression [21,22], and our data are completely in line with 
Table 2 Effect of SHBG on the expression of estradiol-regulated genes in MCF-7 cells

\begin{tabular}{|c|c|c|c|}
\hline \multirow[t]{2}{*}{ Gene Name } & \multirow[t]{2}{*}{ Gene Bank No. } & \multicolumn{2}{|c|}{ SHBG/estradiol } \\
\hline & & $48 \mathrm{~h}$ & $72 \mathrm{~h}$ \\
\hline bcl-2 & M14745 & $\begin{array}{l}2.15 \\
(2.47)\end{array}$ & $\begin{array}{l}1.58 \\
(3.44)\end{array}$ \\
\hline BRCA1 & U68041 & $\begin{array}{l}3.51 \\
(3.66)\end{array}$ & $\begin{array}{l}2.00 \\
(1.77)\end{array}$ \\
\hline Cathepsin D & M11233 & $\begin{array}{l}1.82 \\
(1.86)\end{array}$ & $\begin{array}{l}1.66 \\
(1.65)\end{array}$ \\
\hline c-fos & V01512 & $\begin{array}{l}1.62 \\
(1.65)\end{array}$ & $\begin{array}{l}1.52 \\
(1.50)\end{array}$ \\
\hline$c$-jun & AF022805 & $\begin{array}{l}0.68 \\
(0.76)\end{array}$ & $\begin{array}{l}0.53 \\
(0.53)\end{array}$ \\
\hline c-myc & J00120 & $\begin{array}{l}2.87 \\
(2.90)\end{array}$ & $\begin{array}{l}0.57 \\
(2.31)\end{array}$ \\
\hline COX7RP & AB007618 & $\begin{array}{l}1.05 \\
(1.12)\end{array}$ & $\begin{array}{l}1.32 \\
(1.15)\end{array}$ \\
\hline Cyclin D & M64349 & $\begin{array}{l}1.68 \\
(1.66)\end{array}$ & $\begin{array}{l}1.53 \\
(1.52)\end{array}$ \\
\hline EBAG9 & AB007619 & $\begin{array}{l}1.06 \\
(1.02)\end{array}$ & $\begin{array}{l}2.70 \\
(2.43)\end{array}$ \\
\hline EFP & D21205 & $\begin{array}{l}1.47 \\
(1.47)\end{array}$ & $\begin{array}{l}1.38 \\
(1.20)\end{array}$ \\
\hline EGF & X04571 & N.D. & N.D. \\
\hline EGF-R & X00588 & $\begin{array}{l}1.69 \\
(1.65)\end{array}$ & $\begin{array}{c}\mathbf{0 . 5 6} \\
(2.83)\end{array}$ \\
\hline $\mathrm{ER} \alpha$ & NM_000125 & $\begin{array}{l}1.62 \leftarrow \\
(0.34)\end{array}$ & $\begin{array}{l}1.34 \\
(0.37)\end{array}$ \\
\hline $\operatorname{ER} \beta$ & АВ006590 & N.D. & N.D. \\
\hline HMG1 & NM_002128 & $\begin{array}{l}1.19 \\
(0.95)\end{array}$ & $\begin{array}{l}1.56 \\
(1.19)\end{array}$ \\
\hline H.ras & NM_005343 & N.D. & N.D. \\
\hline Keratin 19 & NM_002276 & $\begin{array}{l}1.96 \\
(2.26)\end{array}$ & $\begin{array}{l}1.91 \\
(1.82)\end{array}$ \\
\hline PR & M15716 & $\begin{array}{l}3.50 \leftarrow \\
(4.75)\end{array}$ & $\begin{array}{l}2.76 \\
(19.9)\end{array}$ \\
\hline PRL & M29386 & N.D. & N.D. \\
\hline pS2 & NM_003225 & $\begin{array}{l}2.75 \\
(2.42)\end{array}$ & $\begin{array}{l}1.89 \\
(2.00)\end{array}$ \\
\hline Telomerase & AF015950 & N.D. & N.D. \\
\hline TGF $\alpha$ & NM_003236 & N.D. & N.D. \\
\hline WISP2 & NM_003881 & $\begin{array}{l}1.58 \\
(1.40)\end{array}$ & $\begin{array}{l}1.20 \\
(1.18)\end{array}$ \\
\hline
\end{tabular}

Table 2 reports the 23 gene spotted on GEArray membrane, their accession codes, and their relative abundance after SHBG/estradiol treatment for 48 or 72 hours; relative abundance was calculated as the ratio between intensity values after/before treatments. Relative abundance of gene expression after treatment with estradiol alone is reported in brackets; genes selectively regulated by SHBG are marked by arrows $\leftarrow$ and bolded

these observations. In MCF-7 cells estradiol upregulates bcl-2 transcription and two different EREs were identified in bcl-2 coding region [23]; moreover the upregulation of bcl-2 was strictly related to estradiol inhibition of apoptosis in this cell line. Stable overexpression of bcl-2 in MCF-7 cells resulted in suppression of apoptosis induced by several chemotherapy agents while pretreatment with the pure antiestrogen ICI 182,780 enhanced induced apoptosis [24].

Another important target of estradiol in breast cancer is the proto-oncogene c-myc. It is well-known how estradiol induces a rapid and robust induction of c-myc in breast cancer cells [25]. The c-myc, in turn, acts on multiple targets that are key cell cycle regulators; in particular, it increases the expression of cyclin $\mathrm{E}$ and CDK4 $[26,27]$. As reported for bcl-2, our data show that estradiol induces c-myc expression that is maximal after 24 hours, and that SHBG abrogates estradiol effect in MCF-7 cells treated for 72 hours. Since aromatase inhibitors and antiestrogens induce growth suppression and cell cycle arrest of breast cancer cells, together with apoptosis induction, and decrease of both bcl-2 and c-myc expression [28], our data suggest that SHBG behavior on c-myc as well as on bcl-2 is like to that of antiestrogens. We also report that SHBG inhibits the estradiol induction of EGF-R. EGF-R or HER1 is a member of the epidermal growth factor family of trans-membrane receptors [29] and it has been reported to be induced by estradiol [30]. Overexpression of EGF-R in breast cancer, that has been reported to occur in up to $14 \%$ of tumors [31], is considered a negative prognostic factor [32], especially if it occurs together with over-expression of other genes such as c-myc [33]. Moreover, EGF-R is involved in a bidirectional cross-talk with estrogen receptors and the activation of the EGF-R-derived signaling pathway could amplify estradiol effect in breast cancer [34]. Therefore, SHBG, abolishing the estradiol induction of EGF-R expression, is able to break the functional loop between the two pathways, reducing breast cancer cell proliferation and growth. Lastly, we show here that estradiol is able to downregulate the expression of its own receptor, $E R \alpha$, effect that has been known for a long time. In fact, a single injection of estradiol determinates an $80 \%$ reduction of binding capacity in cytosol extracts from rat uteri [35]. On the other side, adaptation of MCF-7 cells to long term estrogen deprivation results in MCF-7 hypersensibility to estradiol and leads to an increase of ER [36]. Here we show that SHBG is able to revert the downregulation of ER $\alpha$ induced by estradiol. This effect could also be linked to apoptosis induction and cell growth inhibition, since, as reported by other authors $[37,38]$, both phenomena were observed when ER $\alpha$ expression was increased in association with bcl-2 reduction. As PR modulation is concerned, SHBG completely inhibits the strong upregulation induced by estradiol both at mRNA and protein levels as previously reported [17]; data reported in the present paper, obtained from gene array, further confirm our previous observation.

The selectivity of SHBG effect on gene expression confirms that SHBG regulation of estradiol effect in MCF-7 cells is not a general effect, due to the steroid sequester. As already suggested $[9,15,39,40]$, SHBG is likely to counteract estradiol action in a specific manner. Estradiol regulates the proliferation of breast cancer cells and this property is the key-stone of antihormone therapy with antiestrogens and aromatase inhibitors. Here we show that genes upregulated by estradiol are almost all positive regulators of proliferation (e.g., bcl-2, c-fos, c-myc, cyclin D) or/ and related to more aggressive form of breast cancer (e.g., BRCA1, EGF-R). In addition, we observed that in our set, estradiol caused the downregulation of two genes (c-jun and ER $\alpha$ ). Our data, even though regarding few genes, are mainly in line with the report from Frasor et al. [6] which observed that in general estradiol causes the upregulation of positive proliferation regulator genes and the downregulation of negative proliferation regulators.

Estradiol followed a precise temporal schedule in our study as in previous reports [6] in regulating gene expression. It is noteworthy that SHBG effect was detectable only after 48-72 hours and not at earlier time. It is thus conceivable that SHBG has a late effect on estradiol gene regulation. The absence of SHBG effect 


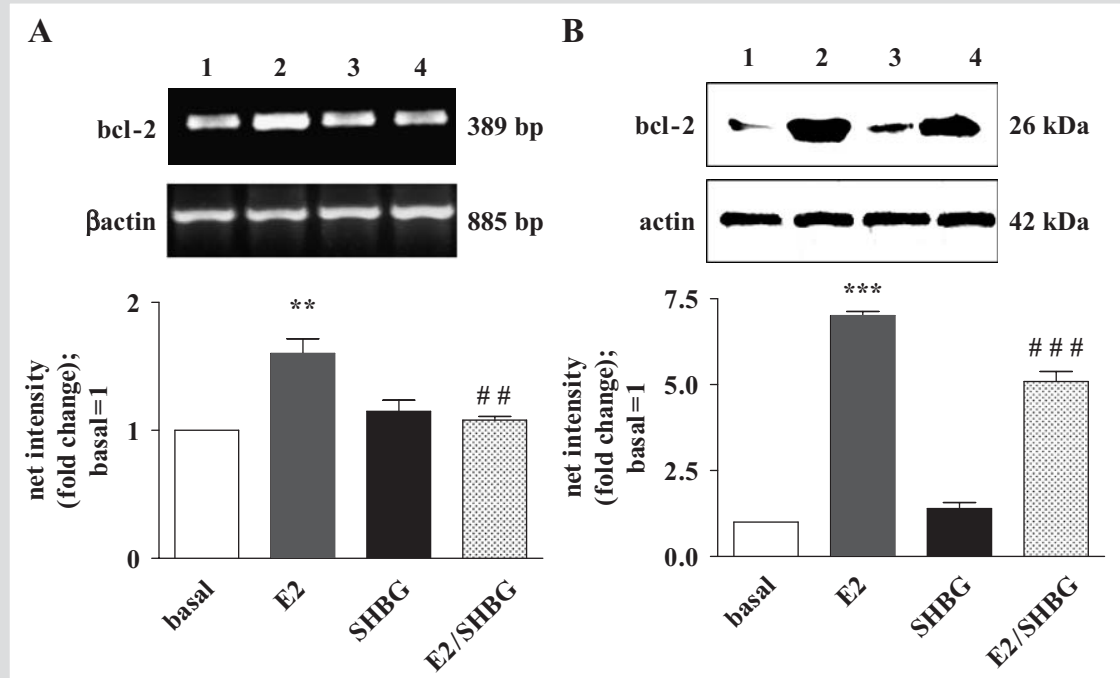

Fig. 1 Effect of SHBG and estradiol on bcl-2. A representative experiment of RT-PCR (panel $\mathbf{A}$ ) and western blot (panel B) for bcl-2 mRNA and protein performed in MCF-7 cells treated with SHBG and estradiol for 72 hours (lane 1: untreated control; lane 2: $10 \mathrm{nM}$ estradiol; lane 3: $50 \mathrm{nM} \mathrm{SHBG;} \mathrm{lane}$ 4: $50 \mathrm{nM}$ SHBG $+10 \mathrm{nM}$ estradiol). Histograms: semiquantitative analysis of RT-PCR and western blot results; net intensity was determined as the ratio between treated cells and untreated controls. Results are expressed as means \pm SEM, $\mathrm{n}=3$. Significance vs. basal: " $\mathrm{p}<0.01,{ }^{* * *} \mathrm{p}<0.001$; significance vs. estradiol: ${ }^{\# \#} p<0.01$, \#\#\# $p<0.001$.

A

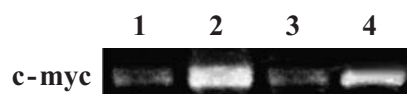
458 bp

B

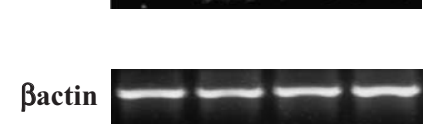
885 bp

actin

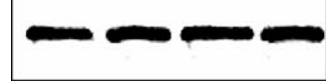

$42 \mathrm{kDa}$
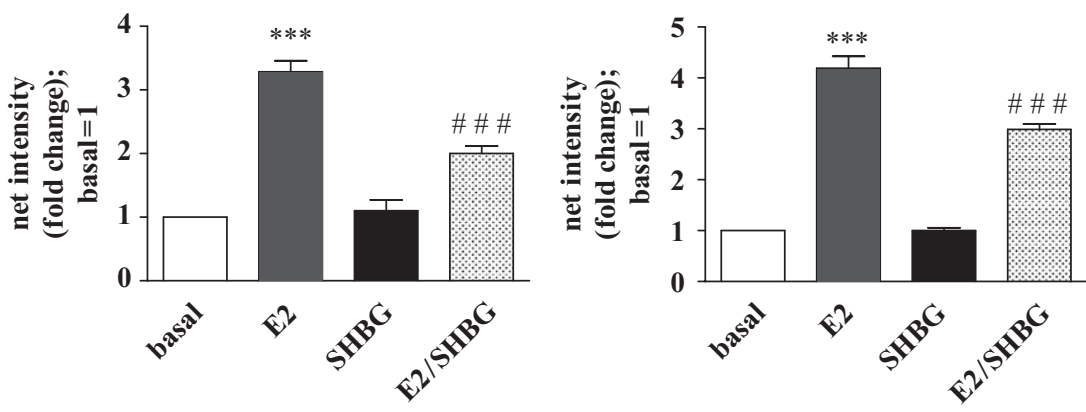

Fig. 2 Effect of SHBG and estradiol on c-myc. A representative experiment of RT-PCR (panel A) and western blot (panel B) for c-myc mRNA and protein were performed in MCF-7 cells treated with SHBG and estradiol for 72 hours (lane 1: untreated control; lane 2: $10 \mathrm{nM}$ estradiol; lane 3: $50 \mathrm{nM}$ SHBG; lane 4: $50 \mathrm{nM}$ SHBG + 10 nM estradiol). Histograms: semiquantitative analysis of RT-PCR and western blot results; net intensity was determined as the ratio between treated cells and untreated controls. Results are expressed as means \pm SEM, $n=3$. Significance vs. basal: ${ }^{* * *} p<0.001$; significance vs. estradiol: $\# \#$ $p<0.001$.

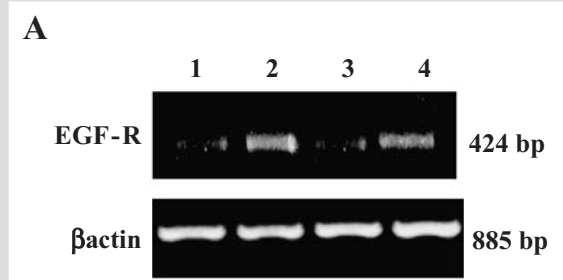

B

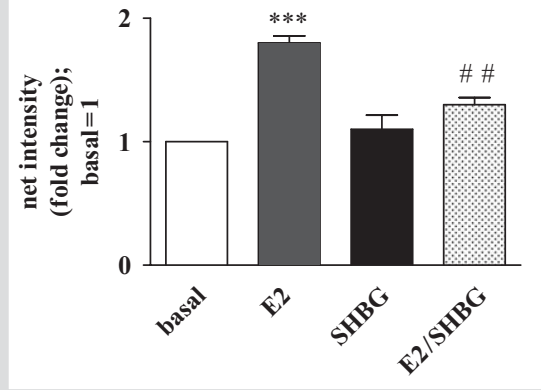

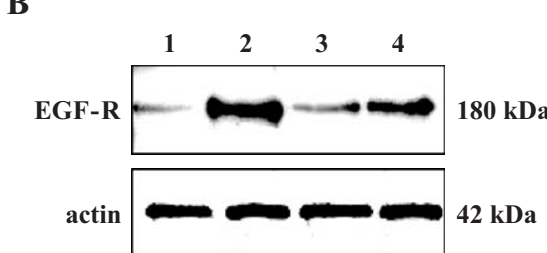

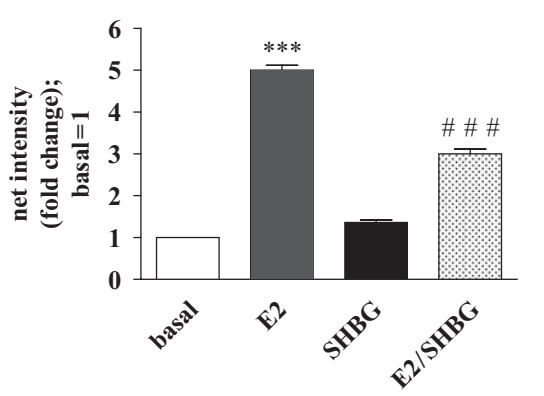

Fig. 3 Effect of SHBG and estradiol on EGFR. A representative experiment of RT-PCR (panel $\mathbf{A}$ ) and western blot (panel $\mathbf{B}$ ) for EGFR mRNA and protein were performed in MCF-7 cells treated with SHBG and estradiol for 72 hours (lane 1: untreated control; lane 2: $10 \mathrm{nM}$ estradiol; lane 3: $50 \mathrm{nM} \mathrm{SHBG;} \mathrm{lane}$ 4: $50 \mathrm{nM}$ SHBG $+10 \mathrm{nM}$ estradiol). Histograms: semiquantitative analysis of RT-PCR and western blot results; net intensity was determined as the ratio between treated cells and untreated controls. Results are expressed as means \pm SEM, $n=3$. Significance vs. basal: ${ }^{* * *} p<0.001$; significance vs. estradiol: ${ }^{\# \#} \mathrm{p}<0.01, \# \# \mathrm{p}<0.001$. at early times supports the hypothesis, recently suggested [15], that SHBG does not interfere directly with the estradiol nuclear receptor pathway. In fact, we recently reported that in MCF-7 cells SHBG [15] is not able to inhibit estradiol-induced transcription in an ERE-tk-luciferase system, while it can interfere with membrane-initiated estradiol pathway [9]. 

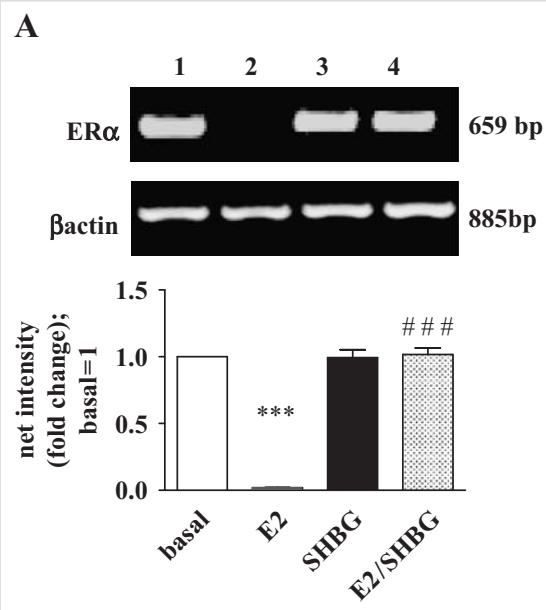

B

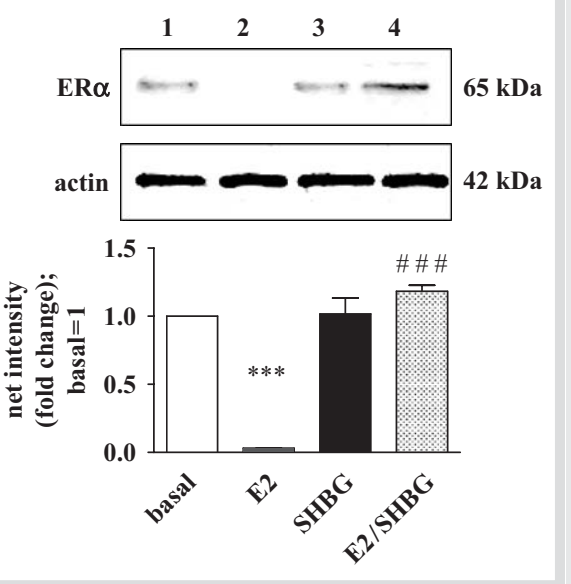

Fig. 4 Effect of SHBG and estradiol on ER $\alpha$. A representative experiment of RT-PCR (panel $\mathbf{A}$ ) and western blot (panel $\mathbf{B}$ ) for ER $\alpha$ mRNA and protein were performed in MCF-7 cells treated with SHBG and estradiol for 72 hours (lane 1: untreated control; lane 2: $10 \mathrm{nM}$ estradiol; lane 3: $50 \mathrm{nM} \mathrm{SHBG;} \mathrm{lane}$ 4: $50 \mathrm{nM}$ SHBG $+10 \mathrm{nM}$ estradiol). Histograms: semiquantitative analysis of RT-PCR and western blot results; net intensity was determined as the ratio between treated cells and untreated controls. Results are expressed as means $\pm \mathrm{SEM}, \mathrm{n}=3$. Significance vs. basal: ${ }^{* * *} p<0.001$; significance vs. estradiol: \#\#\#<0.001.
Since SHBG effect in cells is initiated at membrane level [13], we suggest that the "link" between estradiol and SHBG might reside somewhere between the outer side of membrane and nucleus. We recently proposed [15] that SHBG can reduce ER $\alpha$ activity through ERK inhibition. It is actually known that ER $\propto$ transcriptional activity is increased by ERK-mediated phosphorylation [41] and so SHBG-mediated ERK inhibition can downregulate ER $\alpha$ activity.

In conclusion, our study underlines the ability of SHBG to modulate estradiol-controlled gene expression in breast cancer cells; in particular, SHBG is effective on few selected genes which are involved in cell growth and apoptosis as well as on genes related to cell estrogen-dependence. The effect of SHBG in estrogen breast cancer cells, as previously suggested, is therefore strongly associated to cell growth and estrogen-sensitivity.

\section{Acknowledgments \\ $\nabla$}

This work was partially supported by a Ricerca Sanitaria Finalizzata Regione Piemonte 2002 to N.F. and by the Special Project "Oncology", Compagnia San Paolo to G.B.

\section{References}

1 Dickson RB, Thompson EW, Lippman ME. Hormones and breast cancer in vitro. Hum Cell 1989; 2: 219-230

2 Russo IH, Russo J. Role of hormones in mammary cancer initiation and progression. J. Mammary Gland Biol Neoplasia 1998; 3: 49-61

3 van de Vijver MJ, He YD, van't Veer LJ, Dai H, Hart AA, Voskuil DW, Schreber GJ, Peterse JL, Roberts C, Marton MJ, Parrish M, Atsma D, Witteven A, Glas A, Delahaye L, van der Velde T, Baterlink $H$, Rodenhuis $S$, Rutgers ET, Friend SH, Bernards R. A gene expression signature as a predictor of survival in breast cancer. N Engl J Med 2002; 347: 19992009

4 van't Veer LJ, Dai H, van de Vijver MJ, He YD, Hart AA, Mao M, Peterse JL, van der Kooy K, Marton MJ, Witteveen AT, Schreiber GJ, Kerkhoven RM, Roberts C, Linsley PS, Bernards R, Friend SH. Gene expression profiling predicts clinical outcome of breast cancer. Nature 2002; 415: 530-536

5 Sotiriou C, Powles TJ, Dowsett M, Jazaeri AA, Feldman AL, Assersohn L, Galdisetti C, Libutti SK, Liu ET. Gene expression profiles derived from fine needle aspiration correlate with response to systemic chemotherapy in breast cancer. Breast Cancer Res 2002; 4: R3

6 Frasor J, Danes JM, Komm B, Chang KCN, Lyttle R, Katzenellenbogen BS. Profiling of estrogen up- and down-regulated gene expression in human breast cancer cells: insights into gene networks and pathways underlying estrogenic control of proliferation and cell phenotype. Endocrinology 2003; 144: 4562-4574
7 Hammond GL, Avvakumov GV, Muller YA. Structure/function analyses of human sex hormone-binding globulin: effects of zinc on steroidbinding specificity. J Steroid Biochem Mol Biol 2003; 85: 195-200

8 Caldwell JD, Suleman F, Chou SH, Shapiro RA, Herbert Z, Jirikowski GF. Emerging roles of steroid-binding globulins. Horm Metab Res 2006; 38: 206-218

9 Fortunati N, Catalano MG. Sex hormone-binding globulin (SHBG) and estradiol cross-talk in breast cancer cells. Horm Metab Res 2006; 38: 236-240

10 Porto CS, Musto NA, Bardin CW, Gunsalus GL. Binding of an extracellular steroid-binding globulin to membranes and soluble receptors from human breast cancer cells (MCF-7 cells). Endocrinology 1992; 130: 2931-2936

11 Fortunati N, Fissore F, Fazzari A, Berta L, Benedusi-Pagliano E, Frairia $R$. Biological relevance of the interaction between sex steroid binding protein and its specific receptor of MCF-7 cells: effect on the estradiolinduced cell proliferation. J Steroid Biochem Mol Biol 1993; 45: 435-444

12 Fissore F, Fortunati N, Comba A, Fazzari A, Gaidano G, Berta L, Frairia $R$. The receptor-mediated action of sex steroid binding protein (SBP, SHBG):accumulation of cAMP in MCF-7 cells under SBP and estradiol treatment. Steroids 1994; 59: 661-667

13 Fortunati $N$. Sex hormone-binding globulin: not only a transport protein. What news is around the corner? J Endocrinol Invest 1999; 22: 223-234

14 Fortunati N, Fissore F, Fazzari A, Becchis M, Comba A, Catalano MG, Berta $L$, Frairia $R$. Sex steroid binding protein exerts a negative control on estradiol action in MCF-7 cells (human breast cancer) through cyclic adenosine 3',5'-monophosphate and protein kinase A. Endocrinology 1996; 137: 686-692

15 Catalano MG, Frairia R, Boccuzzi G, Fortunati N. Sex hormone-binding globulin antagonizes the anti-apoptotic effect of estradiol in breast cancer cells. Mol Cell Endocrinol 2005; 230: 31-37

16 Chomzinsky P, Sacchi N. Single-step method of RNA isolation by acid guanidimun thiocyanate-phenol-chloroform extraction. Anal Biochem 1987; 162: 156-159

17 Fazzari A, Catalano MG, Comba A, Becchis $M$, Raineri $M$, Frairia $R$, Fortunati $N$. The control of progesterone receptor expression in MCF7 breast cancer cells: effects of estradiol and sex hormone-binding globulin (SHBG). Mol Cell Endocrinol 2001; 172: 31-36

18 Thompson CB. Apoptosis in the pathogenesis and treatment of disease. Science 1995; 267: 1456-1462

19 Craig $R W$. The bcl-2 gene family. Semin Cancer Biol 1995; 6: 35-43

20 Nahta R, Esteva FJ. Bcl-2 antisense oligonucleotides: a potential novel strategy for the treatment of breast cancer. Semin Oncol 2003; 30: 143-149

21 Kandouz M, Siromachkova M, Jacob D, Chretien Marquet B, Therwath A, Gompel A. Antagonism between estradiol and progestin on Bcl-2 expression in breast-cancer cells. Int J Cancer 1996; 68: 120-125

22 Lapointe J, Fournier A, Richard V, Labrie C. Androgens down-regulate bcl-2 protooncogene expression in ZR-75-1 human breast cancer cells. Endocrinology 1999; 140: 416-421

23 Perillo B, Sasso A, Abbondanza C, Palumbo G. $17 \beta$-estradiol inhibits apoptosis in MCF-7 cells, inducing bcl-2 expression via two estrogenresponsive elements present in the coding sequence. Mol Cell Biol 2000; 20: 2890-2901 
24 Burow ME, Weldon CB, Tang Y, McLachaln JA, Beckman BS. Oestrogenmediated suppression of tumour necrosis factor alpha-induced apoptosis in MCF-7 cells: subversion of bcl-2 by anti-oestrogens. J Steroid Biochemistry Molec Biol 2001; 78: 409-418

25 Shang $Y$, Brown M. Molecular determinants for the tissue specificity of SERMs. Science 2002; 295: 2465-2468

26 Santoni-Rugiu E, Falck J, Miland N, Bartek J, Lukas J. Involvement of Myc activity in a $\mathrm{G}(1) / \mathrm{S}$-promoting mechanism parallel to the $\mathrm{pRb} / \mathrm{E} 2 \mathrm{~F}$ pathway. Mol Cell Biol 2000; 20: 3497-3509

27 Hermeking H, Rago C, Schumacher M, Li Q, Barrett JF, Obaya AJ, O'Connell $B C$, Mateyak MK, Tam W, Kohlhuber F, Dang CV, Sedivy JM, Eick D, Vogelstein B, Kinzler KW. Identification of CDK4 as a target of c-MYC. Proc Natl Acad Sci USA 2000; 97: 2229-2234

28 Thiantanawat A, Long BJ, Brodie AM. Signaling pathways of apoptosis activated by aromatase inhbitors and antiestrogens. Cancer Res 2003; 63: 8037-8050

29 Roskoski $R$, Jr. The ErbB/HER receptor protein-tyrosine kinases and cancer. Biochem. Biophys Res Commun 2004; 319: 1-11

30 Berthois Y, Dong XF, Martin PM. Regulation of epidermal growth factor-receptor by estrogen and antiestrogen in the human breast cancer cell line MCF-7. Biochem Biophys Res Commun 1989; 159: 126-131

31 Ro J, North SM, Gallick GE, Hortobagyi GN, Gutterman JU, Blick M. Amplified and over-expressed epidermal growth factor receptor gene in uncultured primary human breast carcinoma. Cancer Res 1988; 48: $161-164$

32 Spyratos F, Delarue JC, Andrieu C, Lidereau R, Champeme MH, Hacene K, Brunet $M$. Epidermal growth factor receptors and prognosis in primary breast cancer. Breast Cancer Res Treat 1990; 17: 83-89

33 Al-Kuraya K, Schraml P, Torhorst J, Tapia C, Zaharieva B, Novotny H, Spichtin H, Maurer R, Mirlacher M, Kochli O, Zuber M, Dieterich $H$, Mross F, Wilber K, Simon R, Sauter G. Prognostic relevance of gene amplifications and coamplifications in breast cancer. Cancer Res 2004; 64: 8534-8540

34 Levin ER. Bidirectional signalling between the estrogen receptor and the epidermal growth factor receptor. Mol Endocrinol 2003; 17: 309-317

35 Cidlowski JA, Muldoon TG. The dynamics of intracellular estrogen receptor regulation as influenced by 17beta-estradiol. Biol Reprod 1978; 18: 234-246

36 Martin LA, Farmer I, Johnston SR, Ali S, Marshall C, Dowsett M. Enhanced estrogen receptor (ER) alpha, ERBB2, and MAPK signal transduction pathways operate during the adaptation of MCF-7 cells to long term estrogen deprivation. J Biol Chem 2003; 278: 30458-30468

37 Truchet I, Jozan S, Guerrin M, Mazzolini L, Vidal S, Valette A. Interconnections between E2-dependent regulation of cell cycle progression and apoptosis in MCF-7 tumors growing on nude mice. Exp Cell Res 2000; 254: 241-248

38 Detre S, Salter J, Barnes DM, Riddler S, Hills M, Johnston SR, Gillett C, A'Hern $R$, Dowsett M. Time-related effects of estrogen withdrawal on proliferation- and cell death-related events in MCF-7 xenografts. Int J Cancer 1999; 81: 309-313

39 Fortunati N, Fissore F, Fazzari A, Piovano F, Catalano MG, Becchis M, Berta L, Frairia R. Estradiol induction of cAMP in breast cancer cells is mediated by foetal calf serum (FCS) and sex hormone-binding globulin (SHBG). J Steroid Biochem Mol Biol 1999; 70: 73-80

40 Raineri M, Catalano MG, Hammond GL, Avvakumov GV, Frairia $R$, Fortunati N. O-Glycosylation of human sex hormone-binding globulin is essential for inhibition of estardiol-induced MCF-7 breast cancer cell proliferation. Mol Cell Endocrinol 2002; 189: 135-143

41 Coleman KM, Smith CL. Intracellular signaling pathways: nongenomic actions of estrogens and ligand-independent activation of estrogen receptors. Front Biosci 2001; 6: 1379-1391 